\title{
ECONOMY, KNOWLEDGE, FAMILIES: PRACTICES OF APPROPRIATION
}

\author{
ELENA BOUGLEUX
}

\begin{abstract}
The expansion process of a Western multinational corporation in India is investigated using ethnographic tools. In particular the paper deals with the processes of knowledge appropriation enacted by the Indian workforce employed at the Research \& Development Center in Bangalore. Young Indian professionals in the early stages of their scientific or corporate careers seem to take advantage of the investments that the corporation makes in the competitive Indian industrial district, by frequently changing job and finding new positions. The underlying strategy is that of subtracting competences and applied knowledge from the corporation in order to appropriate them and then reinvest them locally and more profitably. Working for a multinational corporation is investigated in its material and metaphorical dimensions, demonstrating the methodological shift required to analyze a very large productive organization through the eyes of its employees. One consequence of scaling down in the ethnographic analysis is that the family is introduced as an economic actor contributing to shaping decisions and public policies.
\end{abstract}

Keywords: corporation; knowledge; development; family; ethnography.

\section{Economy and knowledge on a large and small scale}

Conducting an ethnographic study of a multinational corporation appears to be a vast and diverse research task, dealing with matters such as production, the economy, human capital, and technology. It is a multi-thematic and multi-problematic field of research that pinpoints the crucial relationship between knowledge and hegemony, and between control over scientific resources and their direct management. Laura Nader dedicates her introductory essay in Naked science, anthropological enquiries into boundaries, power and knowledge (1996), to a discussion on the opportunities of ethnographically investigating the ties between knowledge and power systems. Nader clearly affirms that the primary characteristic of a capitalist society is to shape and define human relationships according to economic criteria: sooner or later the social study of communities becomes an economically oriented study. However, although this position is widely accepted, and it can be studied in detail through a variety of case studies in traditional and industrialized societies, the link between economy and knowledge appears more indirect and deserves to be better explained and investigated. 
In this article I will discuss a case study dealing with a specific context, where a strongly industrialized and an emerging economy meet: the process of expansion of a multinational corporation, originally based in the US, within an economically emerging context. The politics of economic expansion enacted by a corporation implies the creation of a direct connection between two worlds that used to be completely separate. The opening of a new corporate branch is a complex sequence of investments that brings about the transfer of people, skills, the definition of new criteria for economic development, a new lifestyle and new approaches to the very idea of work; all generated and rooted within a different socioeconomic setting. The corporation triggers a rapid transition that creates discontinuities and fractures.

To analyze the interaction between these bordering contexts we can start by considering the historically consolidated success of the western development model, which seems to confirm the existence of a strong bond between economic success and the possession of specific forms of knowledge. We will then expand this to consider economically-based relationships established between colonies and colonial powers, and between the northern and southern regions of the world: since modernity, relations of power have hinged on hierarchies of knowledge control. In the course of history, the link between economy and knowledge has proven to be effective in reinforcing the hegemonic roles of their holders, in particular material knowledge involving domestic, medical and military technical and technological development. The combined activation of economic and technological supremacy has made it possible to create a sequence of historicized changes towards what is known as progress, although this is an ambiguous concept that needs to be better defined. The success of one social context over others appears to be firstly a plausible consequence of its economic capabilities, and then of its ability to produce new knowledge, i.e. an applied form of knowledge that can be translated into technology (Harding, 2008).

In fact, in the modern and contemporary eras, societies that have historically produced knowledge have always been the richest and have been those where a surplus of economic resources was made available in addition to the demands of subsistence and basic welfare: these societies systematically invested their resources in surpluses in order to activate knowledge development processes (Arnold, 2000).

Such a view of the virtuous mechanism that links knowledge to development makes it possible to include in the reasoning a few political aspects that shape international relations: the analysis of authoritative mechanisms that regulate contemporary equalities/inequalities makes clear the existing bond between the possibility of maintaining a position of control over crucial forms of knowledge and the subsequent ability to establish and maintain a politically hegemonic role over time (Crouch, 2009). The ability of a society to assume a long-lasting hegemonic role is therefore considered to be a consequence of multiple as well as heterogeneous factors.

Certainly, in a socioeconomic context, wealth is not a sufficient condition for activating procedures capable of producing new knowledge: a society's material wealth can be distributed and spread, just as it can remain entirely concentrated in the hands of a few people, as happens in the circumstances under which profits are generated by Western corporations in developing and emerging countries. Instead, access to knowledge must be spread and distributed on a large social scale in order to bring about a significant 
improvement in the standard of living. Only a quantitative increase in those who manage knowledge can trigger their empowerment and significant social growth; however, even this is not a sufficient condition. In order to study the procedures that practically enable the capital of knowledge to be transformed into economic capital, and thus into a hegemonic instrument, it is necessary to investigate the transition between individual and collective wealth, and between individual and collective knowledge, through a conceptual and methodological shift which creates a link between micro and macro surveys, capable of reading the individual trajectories and social processes within the same conceptual framework.

Basically, the study of communities and their economies, which is in its first reading a study of a collective nature, strongly invokes the necessity for a study of the processes of the generation, management and transfer of knowledge, which are on the contrary processes of a typically individual nature. Therefore, a small epistemological move involves a great methodological shift that calls into the game an ethnographic approach to an economic analysis.

The cause-effect relationship between an increase in economic well-being and the development of knowledge feeds a virtuous circle that is analyzed in detail in the OECD periodical reports on the impact of scientific development on economic growth. The Science, Technology and Industry Scoreboard devotes a quantitative section to comparing educational and research institutions in OECD countries and emerging markets. Two recent reports (OECD, 2009; OECD, 2011) highlight how education paths and scientific careers are strongly expanding in growing economies, especially in India and China; the opposite trend has been recorded in developed countries where scientific careers and related educational paths are becoming less and less attractive, and where technical professions are constantly in decline. The most developed economies that have historically benefited from their advantages in techno-scientific know-how, and can still rely on large numbers of graduates in every area, are paradoxically undergoing a downward trend that is reducing this numerical advantage, and creating the premises for their future weaknesses. In this situation, the corporation is the context within which where the participants of my research move about.

\section{The spatial contexts of the research}

\section{Large scale: The multinational corporation}

The corporation is a productive, economic, political subject with a predominantly technical and scientific profile, whose mission is to transform skills into technology and profit, and vice versa. With a budget comparable to that of an entire country, multinational corporations are determining participants on the global economic scenario. The growth and geographical expansion strategies of a multinational are capable of conditioning the developmental politics of seemingly independent governments, of determining relations of power between different areas of the planet, and of changing the energy and developmental politics of continents for decades (Stiglitz, 2003).

The multinational corporation is an economic and therefore political subject with no social responsibilities (Stiglitz, 2000). It is an opaque, omnivorous, but also welcoming and inclusive productive body. It is ambiguous, perceived as being potentially dangerous, 
deterritorialized and extremely differentiated on the inside, a sort of multi-functional cosmos where all of its devices and sub-organisms agree on the final profit making, under almost any conditions. The corporation in this case study owns four Research \& Development Centers $(R \& D)$ located in three continents, where it performs global production-targeted research. In the company's research centers they have created an exemplary operational link between knowledge, application skills, production and market. The concept turns into the object, the object into profit.

With a logic that was never made explicit in the public documentation, but which becomes fact on the ground, the multinational corporation delocalized its $R \& D$ in very precise geo-cultural contexts, in which specific places were chosen only for certain investments. Its strategy appears to refer to an extremely essential anthropological knowledge, making it possible to optimize the strategies of investments by introducing sociocultural themes into decisional criteria; themes that usually just border the multinational corporation's mainstream. Basically, the corporation selects an emerging context, not only because it represents an economically advantageous choice, but also because it is perceived that better interaction between productivity and research will be is speculated there and because the relationship that can be built between the concept and the object is considered advantageous (Bougleux, 2012b).

On the whole, the propulsive factors behind the multinational company's global action can be neither univocally nor linearly sketched, but among the many contingent and nonseparable elements, it is possible to pinpoint those which have as multiplying factors the possibility of controlling and transmitting one or more of the determining forms of knowledge, developed and kept under control until final production.

\section{Medium scale: The expanding city}

The city of Bangalore, grey and suffocated by traffic, is home to the headquarters of the multinational corporation I have decided to study. It is an ancient city, which can be traced back to the 8th century, but it has only grown significantly in the modern era, yet in a dizzyingly and unsteady way from an urban perspective in the last twenty years. Its population doubled in the nineties, reaching almost five million inhabitants. It is in class I of the Indian metropolises, which contains those with more than one million inhabitants, and of which there are around 30 in India according to the 2001 census. In 2001 the borders of the metropolitan area were redrawn, and with its newly expanded land area Bangalore has more than eight million inhabitants, making it the third largest city in the country.

The city is contradictory and evasive. About $20 \%$ of the population lives in the 800 slums, but it is also the richest city in India, with the largest amount of foreign capital invested in productivity. Its modern urban landscape and slums alternate with no recognizable geometry and no center. The urban faces of the whole city are confused and overlapping. Bangalore does not have good infrastructural network, anything from its streets to basic utilities like water can be cut off in offices for several hours a day. However, it is highly computerized, with wireless networks covering the entire city and there is widespread use of hi-tech mobiles and laptops that work quite well even as one walks through a puddle. More than $40 \%$ of Bangalore's current population has migrated from other parts of India; 
these are young, highly qualified migrants. Many of my informants have tried to find homes around the technology campus where the companies have offices, and demand leads to constant rises in rent, enough to make Bangalore the most expensive city in India, according to the local HRA index.

\section{Small scale: Technological district of electronic city}

Electronic City, a very modern suburb which dominates on the most up-to-date maps is located in southeast Bangalore. It is where the heart of the city beats, an autonomous and parallel universe. The campus brings together the offices of the main hi-tech companies who began opening their India branches there in the 1990s: Wipro and Infosys, two of India's technology companies, also IBM, Oracle, Siemens, Ferrari. With no real land development plan, the multinationals independently bought vast areas of uncultivated or farming land and built millions of square meters of steel and glass using the downtown of any tertiary city as a model; a city within the city made up of offices, large empty streets with no cars, and mirrored windows that reflect the grey sky. The buildings are abstract and somewhat frightening. At first glance, one has a feeling of great enduring emptiness, a costly emptiness with an added value determined by the surplus of knowledge that has steadily flowed through here for the last two decades. This is the Silicon Valley of Karnataka, where the influxes of young graduates are sent for their first work experience, or more often, on return from work experience abroad.

The competition between Indian and foreign companies to snatch up the best technicians, computer technicians and engineers is very high. Young Indians are not loyal to their companies; they change jobs according to the most advantageous offer and move to the company next door with no remorse, as I learned in interviews with betrayed managers and "disloyal" employees. The turnover of specialized technical personnel is extremely high, and thanks to the campus's compactness, it is possible to change jobs without making large changes to the commute home. From the point of view of a technological development company, employee disloyalty can become a serious problem, in terms of weak or a total lack of company secrecy. Therefore, the only possible incentive for fostering a loyal attitude is to keep salaries unnaturally high: the surplus of knowledge that accumulates in E-City's technology district through a competitive mechanism that contains a risk factor, i.e. the loss of sensitive information on research, progressively grows in value. The more competent young professionals are, the more they can afford not to be loyal to their company, and the more their market value increases. Competition among the companies has thus been established over increasing salaries, and the Indians always come out winners.

\section{Ethnographic scale: People}

My informants work in a section of the multinational corporation where mechanical engineering is applied to energy production in the strategic segment of extraction and refining petroleum. Each production section features on the corporation's global organization chart that is framed in divisions: the Engineering Division plans and builds industrial machinery; the Marketing Division sells and installs the machinery all over the world; the 
Infrastructure Division manages and maintains them in the field, selecting and organizing the operating personnel. This is where the choice of location selected for new investments comes into play. The Infrastructure Division almost always employs local personnel, who are purposely trained and have to be retrained periodically. Through this chain of interdependence, the initial commercial link of an industrial order, which is simply an order and a purchase, becomes a link of economic dependence that lasts 'forever'. The relationship between the multinational and the territory is established exactly in this way, by creating the need to manage and then maintain the purchased machinery for the longest possible time in their best conditions.

The company's organization into divisions form Engineering to Infrastructure is an effective example of modular structure and a deliberate way of generating relationships of permanent dependence. The multinational's mechanism of taking root in a particular territory consists of creating an appropriately trained network of employees, who, while working on optimizing, managing and fixing products, actively maintain a preferential relationship of exchange with a commercial partner who always remains the same, and who could not change even if it wanted to. We see this in detail in the workers' points of view.

\section{Engineers and families}

The people who dedicated their time to my research for more than two years in the field, and who involved me variously in their work, are difficult to divide into groups or types; they share many affinities, many qualities and their stories separate them. They can only be tentatively categorized by school of thought, area of interest and a certain critical approach towards their working context. It is also difficult to categorize them by position or nationality. I can say that most are men under 40 . The majority of them have changed workplaces and countries many times in their careers. The only real and determining trait they share is that they all belong to the universe of the multinational corporation's more than 350,000 employees. They are the true multinational, with innumerable ways of perceiving it, living it and telling it.

My informants work in the Indian, Middle Eastern and European offices; I met them during training periods, meetings and while traveling; and on formal and informal occasions, individually and in groups. I deduce that many imaginary multinational corporations exist and perhaps there is one that is more global and inclusive that contains all the others, but that no manager or anthropologist can reach. The multinational is a place in the mind, a projection, a global legend, a topos. It is an indispensable yet evasive interlocutor, a partner of reasoning with seemingly defined lines, but is in fact too undefined. Studying the multinational corporation is like studying modernity: procedurally inevitable but accurately impossible.

The engineers at the Research \& Development Center in Bangalore are very interested in my research, willing to stop work and allow me some time, more than I expect and can manage initially. They are all students of Training on the Job led by a French senior engineer, D. F., who has worked towards their "scientific emancipation" with them for four months, when they will have to form an independent work group. They are all Indian, but almost none are from Bangalore. Most of them studied engineering in Chennai at the Indian Institute 
of Technology Madras, a prestigious scientific institute established after independence (Bougleux, 2012a).

It is impossible to discuss a study path or a career without easily and automatically including the family, a central and recurring theme. The family recurs repeatedly in discussion and in the imaginary. It is the real permanent referent of young professionals. Their relationship with the family legitimates their public lives and dictates the rules of their private lives. The family is profusely thanked in every phrase, word and gesture for having made the costly studies possible. Often the decision to spend limited family capital on higher education is a break with tradition, occurring for the first time in the family's history, or in the history of the entire village. On one hand this tells the story of long-term rural illiteracy, and on the other, it praises the right to attend free public primary schools. The most recurring narration story is that of families of limited financial means, investing in their brightest child's studies with pride and the conviction that his educational growth will bring about the professional success of the new India, which is a new society requiring new choices. The underlying assumption is that professional success will certainly constitute the basis of emancipation for the entire family and its social redemption. However, there are side effects: professional and economical emancipation appear to involve a transformation in customs and demand ethical changes that the families are not always willing to accept, such as living independently, living together before marriage, or more freedom in choosing one's look and language.

The family's investment in their children's studies and career is in any case considered a good move by a constantly growing part of the rural population and also in the most traditional environments, but the consequences of emancipation may imply that the extended family loses control over their children's lives deviating away from the plans of the parents. The young professionals perceive this tension, even stronger for young women, and search for a synthesis regarding both individual compromises and the necessity of building a new common identity.

Responsibilities towards the family are always strongly considered, more directly when closer family members are concerned and also indirectly, in a social sense, when involving the public image of one's own group. K. K. tells me about how his life far different from that of his elderly parents: they share their professional son's vicissitudes with the entire village, his travels abroad become a common story, his promotions are experienced as a conquest for all, his story is spontaneously appropriated and widely shared.

When I tell my father on the phone that I have been chosen for a refresher course in Birmingham, I already know that the news isn't enough. I have to give him all the details of the people, the situation, my colleagues, because I know he will tell everything at the meeting, to the family, to everyone, and the story has to be long, very detailed; he has to be ready to answer all of their curiosities and questions.

A. P. affirms that the stories of his professional success create expectations that are then difficult to satisfy. His sisters' dowries are promised according to his salary, the wedding is organized according to his obligations.

If you tell the truth, when you have told everything, then your life belongs to everyone, everyone can tell you what you can and should do, or if you did well or not." "I basically work for the family. 
Social prestige and public recognition, which reflect onto the family's image, seem to become more important than the improved standard of living that they are actually able to achieve. The economic aspect ironically becomes a minor issue, and the wait for a salary that can improve the conditions of their material lives may become really long. Most of my informants, although their salaries are higher than the average Indian salary, still live with their extended families_-parents, children, aunts and uncles; many share numerous rooms, or sleep on sofas, because they are still "the young members of the family". Few have a car and if they have the opportunity to choose between a career promotion and an award trip to the US or Europe, all choose the award trip; it's more prestigious, more constructive, and a story to tell. The salary, of course, stays the same.

The time for my talks, as agreed upon by D. F., the French engineer who welcomed me to her training course, is during work hours, including lunch break and tea break. Topics of conversation fly; there is not enough time for all the stories of villages where they tell success stories of study and work. So I decide to go against the agreement reached in the beginning, and I start meeting the corporation's employees after work. The topics change, along with the tones and pace of the discussion. The first person that I meet after work is a woman, a project leader. After having briefly met her once in her office, K. A. gives me a time to meet in a bar outside the company, and outside Electronic City itself: in Bangalore, in mid-afternoon. K. A. is divorced and lives with her six-year-old son. She organizes her day according to school hours. She arrives at our meeting with her son; they come by scooter, the boy is not wearing a helmet and is standing up. "I work for the Company [this is what she calls the corporation] because it is the only employer who pays me the same salary as they would pay a man in my position." I have still not discussed the economic issue with the Training on the job students, she is the one taking the initiative and the financial aspect seems pressing. Her situation as a divorcee comes to the fore of the discussion:

It isn't possible for a divorced woman in India to have a normal job, up to the standards of your studies and career. A divorced woman has to lower herself to servant, and this is unacceptable for me, and also for my family, for my sisters. They couldn't accept it if I returned to a lower position. They couldn't accept it more than me.

The matter of financial responsibility, and also the responsibility of a social position concerning the family, comes out with her as well, although in a different way. K. A. studied abroad, obtaining a Masters in England after doing a degree at the Indian Institute of Science in Bangalore. Like most of the students from Training on the job, she also claims that studying for a Masters in the UK was the most significant professional experience in her career, not just in her educational profile. What counts is the prestige that comes from experiences in the Western world: the world of information technology in Bangalore is divided into two parts: those who studied abroad and all the others.

K. A.'s situation represents an exception in the already exceptional and rare scene of narrations of women who work in the industry. The corporation's employees are almost all men; the women in these stories play the roles of mothers and sisters; sisters for whom to procure a dowry that measure up to the family's new financial situation, mothers to convince of the opportunities linked to postponing their sons' marriages so as not to hinder their professional advancement. K. A. is one of the few who speak in the first person, talking 
about herself, and seemingly deciding for herself. For her the corporation represents an opportunity to actualize a project of independence.

Some of the engineers from Training on the job consider the salary increase issue from another point of view: during the interviews outside the office the hot topic of company disloyalty comes up; it is a serious issue, which even the managers face openly by now. At all levels of company management the biggest concern seems to be losing the best employees, particularly those in training, or who have just finished training within the corporation. One of the reasons a well-paid position is left so easily is apparently the pressing need to improve daily working conditions; what emerges is that working for the company is profitable, but it can be very stressful. Similar companies within the same Bangalore industrial area of Electronic City impose fewer demands, do not constantly ask employees to work overtime, do not have as many deadlines, and do not require constant job endurance in a stressful environment.

R. T., expert engineer and Training on the job student, who does not want his photo taken, is resolved about a decision he is about to make, to leave the corporation, resign:

The deadlines here are a nightmare, we use all the time we have up until the last minute. Even the last ten hours of the time difference with the US serve to meet the deadline, which means, we have ten more hours than them, we have the day after, before the deadline arrives there, too. The company pays well but the work is too stressful, you never have time to go home. In the end you don't know what to do with the money you put aside. You can't buy a new pc every month.

R. T. is a programmer with a long CV; he has already worked for Siemens and Wipro, the main corporation's competitors. He does not rule out the possibility that this professional phase at the company is just a transition, but he certainly does not want to leave Electronic City. R. T.'s family is apparently not present in his universe, yet his deep-rooted ties with India are even more evident. A new and important motivation emerges more strongly from his words than from those of his colleagues, a motivation that initially pushes him to accept and then easily leave a job as prestigious as the one he has now. The fact is that he is still dependent on a foreign corporation, and "you never get emotionally attached to a foreign company".

R. T. has a conflictual relationship with his foreign employer as if it were some sort of betrayal of his Indian identity. His side of the discussion gives us a glimpse of a sort of modern nationalism, disguised as the desire for professional independence and a need for acknowledgment of his work skills which come from his same background. His acclaimed desire is to make his own human capital, meaning his intellectual resources and surplus know-how, available in his country. "Working for a foreign company serves for learning its secrets, to learn more in little time. Then you can ditch it, a sort of necessary trick." He and his young colleagues repeat like a mantra the slogan "The west is past, the future is us" seen on the murals in Bangalore, and what R.T. tells me clearly explains what it refers to.

\section{History and hegemony, a personal matter}

There is an explicit ulterior reason for accepting a job with a foreign company: immediate professional advancement, the acquisition of skills, and the prospect of being able to resign in the future. This commonly elaborated practice has emerged over time and has been made 
possible by abundant job offers, and it is now experienced and told as a payback; a payback to the Western world, made possible by the new global economic circumstances that put the Western world's once hegemonic economy in the weaker position of asking for collaboration, thus no longer imposing its own conditions (Guha, 1998; Gupta \& Sivaramakrishnan, 2010). The vague concept of the Western world that appears in this essay is metonymically personified by the Western company, and more weakly by the CEO of the corporation, who in this personification of the conflict is betrayed by his employee, the Indian professional. It is a basic schematization, but it has great appeal to my informants.

Against the broad historical horizon where such motivations are justified, the battle against company disloyalty, which is fought with the politics of periodic salary incentives and pay raises, is destined to be a lost battle. Periodic salary incentives and awards for productivity have become a permanent element on the job market at Electronic City: they do not offer a total guarantee to the companies, but at the same time they can no longer be left out. Family budgets benefit from it, growing with repeated promotions, betrayals, frequent interviews and the constant availability of new jobs.

This scenario is a combination of mutated roles and new relationships in contemporary India which, contrary to what has been repeated throughout history, are not created after a mutiny, nor as the effect of a new political season: they are the indirect consequences of the enormous process of the transfer and spread of knowledge and know-how, even if it happens over a limited area like Electronic City. What we called a surplus of knowledge materializes in the emancipation phases that we have described, and in the consequent inevitable acknowledgement of Indian professionals' new values by the highly-specialized job market.

Coming out of Bangalore International Airport one sees a billboard across the boulevard with bright shiny colors that reads in big letters: "Eradicate poverty by modern technology". The goal is clear and here at Electronic City they probably understand how to make it real: transforming village tales into modern stories, sustaining the careers of divorced women, making it possible to create a variable and easy market for a specialized growing work force that up to 15 years ago did not even exist as a hypothesis. How is it possible that an ambiguous and opaque subject like the corporation could trigger such virtuous processes? Is it really the corporation or rather a side effect of being in an unpredictable territory that keeps changing and distorting the effects of its actions?

Even in this case study, acquiring a dynamic perspective by changing the scale helps frame the issue: let us reconsider the individual and the events of the single person instead of the whole company. "The big corporation is like an innocent baby, here in the belly of India." As K.A. tells me, and many others confirm, foreign companies do not understand the structure of India's society. They cannot even determine from the Indian employees' surnames their place in the caste system, or what is left of it today. Everyone likes cast anonymity, the non-Indian employees, the disadvantaged caste members, and all other Other Backward Classes. The subdivisions amongst Indians based on ethnicity, religion and caste seem to disappear inside this company that acts like a world apart; and such leveling, made by real or presumed ignorance of history, facilitates common, though unstructured, forwardthinking: the ability to claim political and technological changes.

Over time I have been able to map out the Research Center's population by nationality: besides Indians, there are Bengalese, Thai, and Filipino employees; there are also junior 
engineers from the US and from the United Arab Emirates on work study or award travel. Clearly for them there is no nationalist reason for choosing to work for a Western multinational corporation: for all the non-Indian employees this is the heart of Shining India, and the work opportunities that open up are simply perceived as new global chances, available for everyone. In the view of the non-Indian employees, the transition towards an IT economy owned and operated by Indians is already a matter of fact, and they are just benefitting from it.

\section{Conclusions}

The case study briefly analyzed here aims at highlighting a number of causal processes that lead to fast and discontinuous changes in economic contexts of all scales, focusing on small scale ones. The main protagonist of this analysis, the corporation, is placed at the center of the social scene playing the crucial role of producer of capital, while simultaneously capable of immediately transferring large amounts of capital from one social setting to another. The productive nature of the corporation, on the other hand, requires further parallel actions closely linked to the investments, but characterized by the need to develop and transfer original and well-determined forms of applied knowledge.

The knowledge reproduced and patented by the corporations in the R\&D in Bangalore, in the years that I have observed, is appropriated by the workers in a specific and focused perspective, breaking the cause-and-effect link between wages and the need for business continuity. Namely, the appropriation of knowledge capital by the corporation's Indian workers is perceived as more urgent and rewarding than a raise in salary, and is intended as a necessary element for fostering a much greater historic emancipation than that of the family and individual business. The transformation of knowledge capital into profit will eventually take place, in the longer term, through the activation of spin-offs and local enterprises, as an indirect effect of the company's original investments. The economic engine of the corporation is required to trigger the whole process, but the results it produces in the local social scenario are largely beyond its own control.

\section{References}

Amselle, J.L. (2008). L'Occident décroché: Enqu te sur les postcolonialismes. Paris: Stock.

Arnold, D. (2000). Science, technology and medicine in colonial India. Cambridge: Cambridge University Press.

Bhabha, H. K. (Ed.). (1990). Nation and narration. London and New York: Routledge.

Bougleux, E. (2009). Scientific methods and creative practices. Evaluation of constraints and possibilities in an experimental research environment. World Futures, 65, 560-567;

Bougleux, E. (2012a). Exploring knowledge flows in a multinational corporation. World Futures, 68,188-196;

Bougleux , E. (2012b). Soggetti egemoni e saperi subalterni. Etnografia in una multinazionale dell'energia. Firenze: Nardini.

Crouch, C. (2011). The strange non-death of neo-liberalism. Cambridge: Polity Press.

Czarniawska, B. (1998). A narrative approach to organization studies. Qualitative Research Methods, 43. London: Sage. 
Das, V. (1998). Structure and cognition: Aspects of Hindu caste and ritual. Oxford: Oxford University Press.

Dirks, N. (2001). Castes of mind: colonialism and the making of modern India. Princeton: Princeton University Press.

Fischer, M. J. (2009). Anthropological futures. Durham and London: Duke University Press.

Foster, R. (2010). Corporate oxymoron and the anthropology of corporations. Dialectical Anthropology, $34,95-102$.

Gorodnichenko, Y., Svejnar, J., \& Terrell, K. (2010). Globalization and innovation in emerging markets. American Economic Journal - Macroeconomics, 2, 194-226.

Guha, R. (1998). Dominance without hegemony: History and power in colonial India. Cambridge: Harvard University Press.

Gupta, A., \& Sivaramakrishnan, K. (2010). The Indian state after liberalization. Los Angeles: Routledge.

Harding, S. (2008). Sciences from below. Postcolonialities and modernities. Durham and London: Duke University Press.

Ilavarasan, P. (2007). Is software work in India task fragmented? A study of software workers in Bangalore. Sociological Bulletin, 56, 383-400.

Keniston, K., \& Kumar, D. (2004). IT experience in India. Bridging the digital divide. New Delhi: Sage.

Knorr Cetina, K. (1999). Epistemic cultures: How the sciences make knowledge. Cambridge: Harvard University Press.

MacLeod, R. (Ed.). (2000). Nature and empire: Science and the colonial enterprise. Osiris, vol. 15.

Nader, L. (1996). Naked science: Anthropological inquiry into boundaries, power and knowledge. London: Routledge.

Nisbett, N. (2007). Friendship, consumption, morality: Practising identity, negotiating hierarchy in middle-class Bangalore. Journal of the Royal Anthropological Institute, 13, 935-950.

Nussbaum, M. C. (2009). The clash within: Democracy, religious violence, and India's future. Cambridge: Harvard University Press.

OECD Observer (2009). Globalisation and emerging economies. Paris: OECD Publishing.

OECD (2011). Science, technology and industry scoreboard 2011: Innovation and growth in knowledge economies. Paris: OECD Publishing.

Polanyi, K. (1971). The great transformation: The political and economic origins of our time. London: Beacon Press.

Prakash, G. (1992). Science "gone native" in colonial India. Representations, 40, 153-178.

Prakash, G. (1999). Another reason. Science and imagination in modern India. Princeton: Princeton University Press.

Radhakrishnan, S. (2008). Examining the "global" Indian middle class: Gender and culture in the Silicon Valley/Bangalore Circuit. Journal of Intercultural Studies, 29, 7-20.

Sapienza, P., Guiso, L., \& Zingales, L. (2006). Does culture affect economic outcomes? Journal of Economic Perspective, 20(2), 23-48.

Seal, A. (1968). The emergence of Indian nationalism: Competition and collaboration in the later nineteenth century. Cambridge: Cambridge University Press.

Sen, A. (1991). On ethics and economics. Oxford: Wiley-Blackwell Publishing.

Sen, A. (2000). Development as freedom. New York: Anchor.

Sivaramakrishnan, K., \& Agrawal, A. (2003). Regional modernities: The cultural politics of development in India. Stanford: Stanford University Press.

Spivak, G. C. (1999). A critique of postcolonial reason: Toward a history of the vanishing present. Cambridge: Harvard University Press. 
Stiglitz, J. E. (2000). Making globalization work. New York: W. W. Norton \& Company.

Stiglitz, J.E. (2003). Globalization and its discontents. New York: W.W. Norton \& Company.

Department of Social and Human Studies,

University of Bergamo,

Piazzale Sant'Agostino, 2

24129 Bergamo,

Italy

E-mail: elena.bougleux@unibg.it 